Roland Lacroix

Institut Supérieur de Pastorale Catéchétique, Paris, France

\title{
Conversion to the Christian faith today
}

\section{Introduction}

Allow me to introduce my input with a presentation of three meetings made recently in the catechumenate of my parish: with two people seeking baptism (I will call them Anne and Viviane), and one who wanted to re-discover the faith (Yves). This first pastoral meeting was an opportunity for these three people to make a first narration of their conversion. This will give us a first insight into conversion to Christianity today. Yves, who is over sixty, gives the place, date and exact time when what he calls a "heart to heart" colloquium with Jesus took place. He described how, on that day, he felt relieved of all the evil that had accumulated in him. This experience was the trigger of his journey. Anne, who is 58 years old, asks for baptism because according to her she is in a situation of suffering due to black magic that her mother and her daughter are exerting on her. Her husband died five years ago. Viviane, finally, is a young woman of 28 years. She says that since she arrived in the area a year ago, she has continually received signs. She wanted to change job to be closer to people and everything worked excellently: as a sales manager, she found a new job immediately as a nurse's aide, her new colleagues are very religious, she found an apartment close to her work and, finally, she realized that from her window she can see two crosses erected on a nearby mountain. Coming from a Protestant background her aunt being an Evangelical missionary, she decided that to this profusion of signs she was to ask for baptism in the Catholic Church to which she attributes the value of tradition.

We cannot prejudge anything about the path ahead of them. But these three examples already show the diversity of conversion situations. A sudden 
conversion, an illness which begets a quest, the interpretation of certain signs in existence that lead to the decision to ask for baptism ... What is striking is that "conversion" at this point is synonymous with "belief". This strength of conviction which entails the experience of conversion can also bring uncomfortable experiences to companions who are interrogated about their own way of living the faith. The most commonly heard sentence in response to these stories is: "Oh, me, you know, I got into it when I was young."

Still by way of introduction, I would like to quote an article from the French daily newspaper $\mathrm{La}$ Croix ${ }^{1}$ published a few years ago, the title was "Conversion, a work of a lifetime." It read: "In addition to the first meeting sometimes sudden, even brutal - with Christ, conversion is always a step by step path, a journey after the one that was recognized as Lord." And also: "The interior change - also referred to as a "change of heart" - can be sudden, even brutal ... but it can also be done in stages, it can take the form of a progressive awareness of the inherent sinfulness, then a decision to welcome grace." The authors added: "There are as many conversions as there are converted persons." This article thus gave three keys to understanding conversion: conversion as an event, conversion as a path with successive steps, and the diversity of conversion experiences.

We cannot but reduce conversion to these three aspects. As the theme of our congress states, conversion is an act that involves a process that requires support. But we can already note the complexity of this phenomenon. Conversion as a phenomenon after all was poorly analysed as such in catechetical theology. Yet, if catechesis is understood and inspired today from the model of the catechumenate, and therefore is seen as an initiation, it cannot ignore the moment of conversion as one of the essential elements of adhering to the faith. Asking questions and analysing conversion from experience then unlocks a large number of issues. Indeed, many are the issues raised. For example: should we oppose conversion as an event, sudden conversion, and conversion understood as a process? Is it possible to objectify conversion knowing that this is a highly personal experience? The fact that anthropologists, psychologists and sociologists attempt at objectifying conversion regardless of the actual content of conversion stories, thus eliminating God, is this not in itself problematic? ...

Before we ourselves work with conversion accounts, I offer four points to try to help you understand conversion to the Christian faith better. My first

${ }^{1}$ La Croix newspaper, 24-25/01/2009. 
point will concern the approaches to conversion in the humanities; then, I will propose a theological approach. I will devote my third point to the relationship between conversion, the catechumenal model and catechesis. Finally, my fourth point will more directly introduce our work around the conversion stories.

\section{Understanding conversion?}

Having given a glimpse at concrete experiences in the introduction does not simply have an anecdotal value. Indeed, conversion is primarily a life experience that we know only because it is narrated and because of its effects on the very existence of converts, "I had an experience that made me change of life," they say. In fact, as Yves Congar writes, for there to be a conversion, "there must have been a personal experience by which one has been interrogated and brought to change something in his/her life." ${ }^{2}$ This phenomenon, which is still amazing, has not ceased to intrigue anthropologists, psychologists and sociologists of religion, who have long been trying to decipher, to clarify the parameters, and to propose typologies. The theological understanding of conversion has created a wide space to different approaches by the humanities.

\subsection{The notion of conversion}

First of all we must recall that the notion of conversion is already present in the philosophical schools of antiquity. These included philosophy itself as a call to conversion by which man returns to his/her original nature (epistrophè), removing the distorsions in which the common person lives and by a profound change of the whole being (metanoia), ${ }^{3}$ moving from ignorance to knowledge of the truth in order to reach a new and wise way of living. Only the philosopher was actually capable of achieving this.

The notion of conversion also has roots in Scripture. The teshuva in the Old Testament is a return to God, a return to the covenant between God and his people. This return is an invitation from God and takes the form of

${ }^{2}$ Y. Congar, La conversion. Étude théologique et psychologique, "Parole et mission" 11, Cerf, octobre 1960, p. 494.

${ }^{3}$ Cfr P. Hadot, Conversion, Encyclopcedia Universalis, http://www.universalis.fr/encyclo pedie/conversion/ (19.03.2015). 
call and response, particularly in the prophetic movement. ${ }^{4}$ This is a sort of a "return / repentance / response" to God's call to a new life, a change of life: from a heart of stone to a heart of flesh (Ezek 11, 19), a new heart and a new spirit (Ezek 18, 31). Christianity receives the experience and the language of conversion from the Old Testament. But the exegete Pierre Heudebert writes, "to the prophetic metanoia - including that of the Baptist - that is an invitation for a return to the God of the Covenant, there follows a New Testament metanoia, which is addressed to all people, Jews or pagans. This metanoia is above all an invitation to a new beginning which is none other than the faith." ${ }^{5}$ Conversion is a coming to the faith, a faith relationship with God, a liberating relationship of all that blocks and alienates the person. In the Gospels, to convert is to answer the call of Jesus of Nazareth, believing in his words and gestures which is what gives life, and to turning to God and gain access to a new dignity as children of God.

Today, the notion of conversion has entered into the common language of people. This means that conversion has taken on the meaning of a return to the self and of a radical transformation of life, thus preserving its original etymological meaning. ${ }^{6}$ But in secularized societies, where anything transcendent is put aside, conversion is cut down to size and reduced to a process of inner liberation, of realization or of self-development. This is so much so that it has entered the sphere of the personal and is today considered as belonging to the private sphere of existence. It became normal to separate the notion of conversion from its religious character. However, this phenomenon continues to exist in all religious traditions.

In any case, among researchers there is a consensus regarding conversion: ${ }^{7}$ all approaches emphasize that this is a radical existential process of transformation

${ }^{4}$ Cfr Infra, 2.2, "Conversion understood as vocation".

${ }_{5}^{5}$ P. Heudebert, La metanoia, des Septante à Saint Luc, in: Département des études bibliques de l'Institut Catholique de Paris, La vie de la Parole. De l'Ancien au Nouveau Testament, Paris, Desclée, 1987, p. 366.

${ }^{6}$ The Latin word conversio refers to two Greek words with a different meaning: epistrophè, "a shift in direction" with the idea of a return to the beginning, to oneself, and metanoia, "a change of mentality" with the idea of a mutation and a rebirth: "A polarity faithfulness-break with the past which has strongly marked Western consciousness since the appearance of Christianity". P. Hadot, Conversion.

7 Some researchers speak of "convertology" to describe the research on conversion in the humanities. This term is used by Stéphane Tank-Storper, in: S. Tank-Storper, Le converti comme 
that opens the person up to a better humanity and to a surplus of meaning. This touches all dimensions of life: psychological, personal, relational, spiritual ... Conversion thus has an eminently social aspect affecting not only personal identity, but also one's relationship to the community and to the social structure. It is a complex phenomenon.

\subsection{The anthropological and psychological approach to religious conversion}

For anthropology and religious psychology, the complexity of conversion is explained by the different transformation modes which it contains: break with the past, interior "reorganization", necessary reorientation in society ... If psychology has had a longstanding interest in conversion, it is its suddenness that has most intrigued it. In fact, the realisation of a change, of experiencing a transformation as irreversible often tends to hide the steps of what came before and what is to follow. Yves Congar described this phenomenon: "There are [...] slow and sudden conversions, but often in the latter, the time of abrupt decision was preceded by preparations and it is followed by many other things which need to be done." What Yves Congar calls the "new principle of synthesis" may have been acquired or suddenly received by instant illumination, while the "structures of reason or responses" come at a later time. Thus, while it is true that psychologically, conversion induces a profound and even radical transformation of the person, ${ }^{9}$ the very fact of talking about "stages" of conversion is opposed to the idea of an instant reversal and it means a transformation unfolding in a certain period. The change in identity that is undertaken, even if this is sometimes experienced as a sudden rupture, involves a whole process linked to one's living experience, and a relation to oneself and to others. ${ }^{10}$ This does not mean that in one's life, there is

figure paradoxale de la stabilité religieuse, in: B. Bakhouche, I. Fabre, V. Fortier, Dynamiques de conversion: modèles et résistances. Approches interdisciplinaires, Bibliothèque de l'École des Hautes Études - Sciences religieuses $n^{\circ}$ 155, Turnhout, Brepols 2012, p. 19.

${ }^{8}$ Y. Congar, La conversion..., p. 503-504.

9 A transformation which brings about both a change in one's deepest identity and a sense of belonging.

${ }^{10}$ Cfr P.-Y. Brandt, Leétude de la conversion religieuse en psychologie de la religion, in: P.-Y. Brandt et C.-A. Fournier (dir.), La conversion religieuse. Analyses psychologiques, anthropologiques et sociologiques, Genève, Labor et Fides, 2009, p. 40. 
no "proper or opportune moment for conversion." ${ }^{11}$ The transformation brought about by conversion itself is a complex process that articulates both interior psychic experience and recognition by others. For some researchers in psychology this is the result of an unconscious process that prepares the person for this revelation.

Note the importance of being able to narrate the conversion, since the "new" identity of the converted person is achieved through a narrative identity ${ }^{12}$ that contributes to the construction of the "new" person. In fact, as the psychologist Pierre-Yves Brandt explains, "for an identity transformation to become effective in the dialogue between the individual and society, it should speak and recount itself. In this sense, religious conversion does not exist independently of the narrative that is narrated. It is due to this that the study of conversion narratives plays an important role." ${ }^{13}$ The American anthropologist Susan Harding goes even further regarding the importance of witness when in her study of Fundamental Baptists she says that this witness is "the practice itself, the rite of conversion." Let us add that conversion testimonies sometimes have the effect of a form of mistrust vis-à-vis a conversion that seems to encapsulate the converted in a particular language, in a particular behaviour and even in a blind adherence to requirements by the religion. ${ }^{15}$

\subsection{The sociological approach to religious conversion}

In fact it is the sociological approach to conversion that has produced most works today. ${ }^{16}$ The sociologist of religion Danièle Hervieu-Léger who is an authority

${ }^{11}$ Y. Congar, La conversion..., p. 510. "It is certain that conversion often occurs after a crisis characterized by a certain imbalance from which we want to move out, or of loss of internal security" (p. 509).

12 Cfr P. Ricoeur, Temps et récit III. Le temps raconté, Paris, Le Seuil 1985; P. Ricoeur, Soi-même comme un autre, Paris, Seuil 1990.

13 P.-Y. Brandt, Létude de la conversion religieuse en psychologie de la religion, p. 40.

${ }^{14}$ S.-F. Harding, Convicted by the Holy Spirit: The Rhetoric of Fundamental Baptist Conversion, "American Ethnologist" 14/1 (1987), p. 167, as cited by P.-Y. Brandt.

15 André Godin nevertheless says: "When one is talking of a story about a sudden conversion, one must never forget that this is a fact after the actual event, of a reconstructed past where the Christian life preceding the conversion was often underestimated". A. Godin, Psychologie des expériences religieuses: le désir et la réalité, "Champs nouveaux" Series, Paris, Le Centurion 1981, p. 85.

${ }^{16}$ In fact, research on conversion is often interdisciplinary. Cfr Cahiers détudes du religieux. Recherches interdisciplinaires, they are available online: http://cerri.revues.org (8.06.2016). 
because of her work on Christianity, ${ }^{17}$ in the preface of a recent collective work, discusses the phenomenon of a widespread "episodes of conversion," ${ }^{18}$ and this can be found in all cultural areas and in all religious traditions. According to her, in Western Europe conversion must be understood broadly. She offers this as a model of experiences of religious conversion: on the one hand, the classic case of a change of religion, and on the other what she calls the "re-claiming (re-endorsement)" of one's religion by an adult (she gave the example of "persons who returned to the faith"), finally the passing on from not belonging to a religion to belonging to a religion.

The sociological approach tends to make conversion today, a kind of standard for identifying a genuinely religious person, that is to say, an individual choosing his/her religion and engaging them in a fully conscious way. What would characterize religion in the postmodern context is precisely this assertion of the believer as an autonomous subject. But the phenomenon of conversion above all shows, and this is contrary to what sociologists expect, that religion still plays an important role in the formation process of personal and social identities in modern societies. At the same time and paradoxically we still have "the fluid, unpredictable, and at times even chaotic characteristics, with which these paths of identification are often endowed and which do not necessarily lead to a stable belonging to a particular religious denomination." ${ }^{19}$ The converted person is therefore now a "paradoxical figure" on two levels: s/he reveals religious stability, where stability is now problematic; the person is also a possible anchor to re-enable religious authority, while the contemporary context of the believer affirms the autonomy of the believing person. ${ }^{20}$ It is as if the two now traditional figures in the sociology of the converted and of the pilgrim ${ }^{21}$ are no longer opposed to each other, but simply cross each other's paths. Anyway, in our secularized and "fluid"22 societies, paths of conversion are likely made up of multiple re-directions.

${ }_{17}$ Cfr for example D. Hervieu-Leger, Le pèlerin et le converti. La religion en mouvement, Paris, Flammarion, 1999.

18 D. Hervieu-Leger, L’impératif de la conversion. Réflexions sociologiques sur la fabrique contemporaine des identités religieuses, in: B. Bakhouche, I, Fabre, V. Fortier, Dynamiques de conversion..., p. 8.

19 D. Hervieu-Leger, L'impératif de la conversion, p. 9.

${ }^{20}$ Cfr S. Tank-Storper, Le converti comme figure paradoxale de la stabilité religieuse, p. 24.

${ }^{21}$ Cfr D. Hervieu-Leger, Le pèlerin et le converti...

${ }^{22}$ Cfr Z. Bauman, La vie liquide, "Les incorrects” Series, Arles, Ed. du Rouergue, 2006. 
Sociologist Danièle Hervieu-Léger also presents the figure of the convert as an "analyser of the ultra-modern religious landscape."23 She raises two particularly interesting points for our debate.

The first point concerns the relations between converts and the institution. Sociological analysis usually posits one vis-à-vis the other. On one hand the approach of the converted person - a journey which demonstrates that "both divine initiative which is the cause of the desire for conversion and the freedom of those who commit themselves" - and on the other the institution which is supposed to validate and to organise this highly personal approach. The Sociologist states that normally this validation constitutes "eliminating 'wrong reasons' to convert and verifying the proper assimilation $[\ldots]$ of beliefs $[\ldots]$ and practices." Today, however, conversion is "less under the control of an institution that guarantees orthodoxy". She explains this change: This feature of the contemporary scene of conversions in the Christian sphere tends to subordinate, or even simply to reduce this phase of validation to the authenticity of public testimony of the journey of the converted person: what is most important is the ability to bear witness in front of the community to the uniqueness of his/ her personal journey, and to personally received grace which is the principle of his/her religious commitment. ${ }^{24}$

The testimonies of conversions, conversion stories would thus take the role of a validation of faith. Now, we can see this observation in the light of the catechumenal practice as it has developed in France. Indeed, in the sixties, conversion was an important step in the catechumenate, a step which was a move from the "pre-catechumenate" to that of a "catechumen", as the theologian Pierre-André Liégé explained at the time. It is not enough to attend a catechumenate centre to be a catechumen, he said, because "the catechumen must be a convert who did everything to mature his/her conversion." ${ }^{25}$ Today we can say that this step has almost disappeared and the focus is more on the testimony of conversion

${ }^{23}$ D. Hervieu-Léger, L’impératif de la conversion..., p. 9.

${ }^{24}$ D. Hervieu-Léger, L’impératif de la conversion..., p. 11.

25 P.-A. Liégé, Critères pour l’admission au catéchuménat, in: Problèmes de catéchuménat, Supplément de la revue Catéchèse d'Avril 1962, p. 223. Odile Arnold, of the catechumenate of Paris, in the same supplement, also believes that it is "a serious mistake" to "deal with an 'unconverted' catechumen". Hence the important distinction between the "pre-catechumenate" and "catechumenate", and the notion of "catechumenal conversion". O. Arnold, La conversion à la foi, p. 48-49. 
rather than on the actual criteria of discernment regarding the conversion of the catechumen.

The second point concerns the relationship of converts to the community. A shift has taken place that goes to the point of overthrowing the validation of conversion. Danièle Hervieu-Léger explains that today it is the community "which must demonstrate the ability of the new believer, at least as much as the convert must demonstrate his/her compliance (or the desire to conform) to the criteria of community membership." ${ }^{26}$ Again, this reflection partly illuminates what is experienced in the adult catechumenate. Indeed, we have long been trying to interpret the difficulty of integrating new converts to the inability of the Christian communities to welcome them. Today, the short-sightedness of communities is often opposed to the freshness and conviction of the newly converted. It is symptomatic that the sociologist here takes the "Catholic catechumenal communities"27 as an example. She explains the difficulty of integrating the newly baptized as "ordinary" people in relation to the strong relational intensity in catechumenal groups and to the "extraordinary" nature of the catechumenal experience and its temporary nature. Here she is pointing to a recurring difficulty of the catechumenate, that of the perseverance of the neophytes. The reflection of the sociologist invites us to consider this problem from point of view of the difficulty in conversion itself and to its accompaniment.

As we can see, the approach of the humanities remains relevant for understanding conversion. These non-theological approaches can show quite stimulating and enlightening aspects of the phenomenon. Although, as the theologian Marc Dumas observed, they "no longer see or have forgotten that theology is practically part of the DNA of conversion." ${ }^{28}$ It remains therefore essential to deepen the theological character of conversion because, anyway,

${ }^{26}$ D. Hervieu-Léger, L'impératif de la conversion..., p. 11.

${ }^{27}$ According to Danièle Hervieu-Léger, in France "undoubtedly and unjustly, less attention is paid to visible phenomena of conversions to the Reformed Protestantism or to Roman Catholicism. Although these are not quantitatively massive, they reveal the mobility of individual trajectories of religious identification quite well, a mobility which is a major feature of our contemporary religious landscape”. D. Hervieu-Léger, L'impératif de la conversion..., p. 8.

${ }^{28}$ M. Dumas, Convertir la conversion. Une tâche théologique infinite, in: B. Bakhouche, I. Fabre, V. Fortier, Dynamiques de conversion..., p. 93. Marc Dumas here repeats an expression used by Lewis R. Rambo, in: L.-R. Rambo, Anthropology and the Study of Conversion, in: A. Buckser, S. D. Glazier (ed.), The Anthropology of Religious Conversion, Lanham Md, Rowman \& Littlefield 2003, p. 214-215. 
approaches by the human sciences tend to empty its contents. In fact, they work from the "outside", as if stories of conversion had no deep sense and no content. ${ }^{29}$ For scientific hypotheses, they render the spiritual content of the stories meaningless, and from these they draw conclusions that remain beyond the content. Is it not a paradox to study an experience while neglecting what is the most intimate, the heart?

If the current period of crisis in the transmission of faith nourishes research on conversion, so it must be all the more opportune for us to resume anew a theological reflection on this experience, to "re-theologise" this notion in some way. ${ }^{30}$ A phenomenologist of religion in 1948 had already written: "We can describe the structure of conversion without adding [the] divine action as part of our understanding." ${ }^{31}$ The use of the human sciences remains essential, but understanding conversion will be lacking if it does not pass through a discourse on God. Thus, if each approach enriches our understanding of the phenomenon of conversion, we cannot exclude the theological approach. This is the focus of my second point.

\section{A theological approach to Christian conversion}

The phenomenon of conversion remains complex and a too narrow theological interpretation or a rapid browsing of certain conversion testimonies could lead to an understanding of God's intervention which is too "mechanical" and an understanding of the human being who would be a kind of puppet in God's hands. In fact, theology has traditionally considered conversion as being the result of a call, emphasizing the act of God who makes the new birth of the converted person possible. Theology also maintains that this gift of God

29 "The methodological atheism of sociology which constitutes its scientific pretensions will lead to refrain from exploring a religious experience and the construction of the identity of the believer to focus on social effects on the grounds of affiliation. This atheism is obviously the opposite of the theological method which is immediately within a framework of faith". J.-M. Donégani, Les récits de vie, in: G. Routhier et M. Viau, Précis de théologie pratique, Montréal/Bruxelles/Paris,Novalis/Lumen Vitae/Ed. de l'Atelier, 2004, p. 113.

${ }^{30}$ Cfr J.-L. Souletie et R. Lacroix, La conversion et le devenir chrétien, "Lumen Vitae" (2013-4), p. 422.

${ }^{31}$ G. van der Leeuw, La Religion dans son essence et ses manifestations, Paris, 1948, cited by Y. Congar, La conversion..., p. 522. 
requires on the one hand to be welcomed and made personal and on the other hand it is necessary for the convert to appropriate the salvation offered. If God regenerates the person, the human on his/her part needs to turn voluntarily to God. Theological traditions stress that the process of conversion is a divine action as much as it is a human action. To say it in the words of Yves Congar: If Catholic theology affirms without ambiguity a first and decisive role of a force coming from God, grace - that anticipates the human being who receives it without merit, and in such a way that the beginning of conversion is the fruit of grace - it nevertheless strongly affirms the reality and proportion of human freedom. Since the time of St Augustine, theology has even tried to analyse the alternating game of freedom and grace as closely as possible [...]. The God of grace and the freedom of the human being approach each other in a kind of dialogue and reciprocal conditioning [...]. The religion of the Bible, the religion of the Covenant is of a dialogical nature. ${ }^{32}$

In fact, it is first the person who is in conversation with God who is involved in the conversion. The same person is a constitutive part of the same dialogue. The Constitution on Divine Revelation of the Second Vatican Council, Dei Verbum, affirms the link between conversion and faith in the same way.

\subsection{In Dei Verbum, conversion and faith are inextricably linked ${ }^{33}$}

The first theological interpretation that could be made of conversion is that God still reveals himself today, with conversion being the first response to this revelation. The conciliar Constitution on Divine Revelation Dei Verbum, paragraph 5, recalls the reception of this revelation: "The obedience of faith" (Rom. 13:26; see 1:5; 2 Cor 10:5-6) "is to be given to God who reveals, an obedience by which man commits his whole self freely to God, offering the full submission of intellect and will to God who reveals," and freely assenting to the truth revealed by Him.

Therefore, the answer to Revelation constitutes the "entire human being." It is an integral act, a conversion. But, on the other hand, Dei Verbum recalls faith: To make this act of faith, the grace of God and the interior help of the Holy Spirit must precede and assist, moving the heart and turning it to God, opening the eyes of the mind.

\footnotetext{
32 Y. Congar, La conversion..., p. 513.

${ }^{33}$ Cfr J.-L. Souletie et R. Lacroix, La conversion et le devenir chrétien.
} 
Thus faith is expected from the "heart" of the human being, from his/her "spirit" through intelligence and will, from his/her conversion. But at the same time it comes from God, it is God who makes the human being turn to him, sets him/her in motion. It is God who opens the human being to his self-revelation, and converts him/her.

If paragraph 5 of Dei Verbum does not explicitly contain the word "conversion", the text still aptly describes the inseparable link with faith. Understood as turning back and giving one's consent, as a roundabout turn for approval, conversion is closely linked with the revelation of God and it is God's grace that retains the initiative. If conversion is sometimes described as a decision, as a voluntary act, the Christian faith insists that the will of man itself has already been moved by God before. This is what Yves Congar finds in conversion narratives: A statement constantly returns [...] in conversion stories [...]: the affirmation of a sovereign action of a living Person, but transcendent and invisible. The story that [converts] have experienced does not only seem to be directed towards God, but it is led by God, and they testify to his initiatives and this behaviour responds in a remarkable way to what theologians call the action of Grace. The last contribution, that by which everything becomes clear and decided does not come from the person. It is the action of Another inside them. ${ }^{34}$

Catechumens are still witnesses of this today. When asked what put them on the way, they sometimes spot a before and an after - this or that event, condition or word triggers the process, as I mentioned in the introduction - or several different moments or experiences, but their journey never boils down to the simple decision to become a Christian. It is in contact with the Word of God they are led to ask the question: "Who has worked well inside me so much so that my view of life changes, so that I find a new meaning to my existence, so that my future re-opens in front of me once again? ..." So they need time to discern the action of the Spirit in their journey, a Spirit who was present from the very beginning of their passage.

\subsection{Conversion understood as vocation}

If conversion and faith are intimately linked with the act in which God reveals himself - as the General Directory for Catechesis also reaffirms: "The Christian faith is, above all, conversion to Jesus Christ" (§ 53)-conversion does not stop

${ }^{34}$ Y. Congar, La conversion..., p. 511. 
at key moments. It also involves a search for the knowledge of God, of the truth. But a truth that is no longer understood as a goal to be achieved, as a number of truths to believe in and thus assimilating them would be enough. The journey of catechumens and their accompaniment are also significant in this sense. One cannot know when a conversion takes place because this is not controllable. But there is an important moment when the catechumen discovers, through reading the Bible and "ecclesial initiation", that the aim is not to reach the truth, but it is the truth which "holds" and even "supports" this journey from the very beginning because this truth is Christ himself. It is then up to the catechumen to "accept and believe this truth." ${ }^{35}$ Conversion is thus part of a process, because the knowledge of God is never immediate. This is a consent-approach to truth as gift, consent that goes through a spiritual struggle. In fact, conversion has to do with one's vocation and catechumens ask, "What is God calling me to?" Now conversion seen as a calling cannot do away with a time of discernment. ${ }^{36}$

This proximity between conversion and vocation is an important issue that is related to the question of prophecy. In the early days of the contemporary catechumenate in France many high hopes were placed on the convertedcatechumens who were expected to be "prophets" who would bring about the conversion of the context and environment in which they lived - and most catechumens came from the working class, a stratum which by the Church were considered as "lost". The converted had to act as a bridge between "the world of unbelief" and "the world of faith." ${ }^{37}$ While this view may seem outdated today, and maybe even naive, proximity between conversion and vocation has perhaps not been sufficiently explored, especially in the pastoral field.

\subsection{Conversion as a Paschal Experience}

If conversion is closely linked to the Christian faith, as Dei Verbum therefore shows, if it is a calling, this is because it is at the heart of the Easter experience. This is also what the narratives of the apparitions of the risen Lord in the Gospels show. In these stories, conversion does not appear as a natural movement, but as the fruit of an encounter with the Risen One. These are not disciples who

${ }^{35}$ Cfr Dei Verbum $\$ 5$.

${ }^{36}$ One can read the three stories of the "conversion" of Paul (Acts 9; Acts 22 and Acts 26) as stories of callings.

37 O. Arnold, La conversion à la foi, p. 40. 
made the decision to encounter Christ, it is Christ who after his death appeared to his disciples. A typical example is the story of the disciples of Emmaus, since the change is physically manifested by the return of the disciples to Jerusalem (Lk 24: 13-35). In this case the conversion process was represented by the journey to Emmaus and back. Another example of a physical turnaround is that of Mary when Jesus calls her by her first name in the garden. In this case the conversion process is represented by the dialogue with the man whom she did not recognize immediately as Jesus and then by two round about turns (Jn 20: 11-18). In conversion what can be seen or understood provokes a turning back to God, but this is not only the fruit of a moment and it cannot be achieved without a journey towards knowledge of God. Other examples indeed show how conversion and knowledge of God are part of the same process. The doubt of Thomas crumbles only when Jesus said, "Put your finger here" (Jn 20, 27). And when Paul met Jesus on the road to Damascus, he remains "dead" (without seeing or eating or drinking) for three days (Acts 9: 9), and he needs Ananias and to open his eyes.

In terms of personal experience, conversion is therefore a form of a realignment exercise which leads to destabilization. Access to the new coherence and to the new birth (Jn 3) after the conversion always requires some "labour" by the person and thus requires a period of time. The dictionary of spiritual life says that "a conversion is not about a particular moment in life [...]. A genuine conversion is structured on continuous fluctuations, and is deepened through successive stages." ${ }^{38}$ There are usually resistances and conversion provokes a crisis that is not disconnected from the rest of the Christian message itself. Indeed, Christian revelation offers the possibility to think of faith as an experience of crisis. This is due to the structure of the act of faith itself as recalled by the theologian Jean-Louis Souletie: "There is no security nor guarantee of faith, but the Word is always fresh and calls for a new adherence." ${ }^{39}$

If "Christian life is a continuous conversion" as the dictionary of spiritual life says, it is also because it has tensions. Indeed to believe in Christ is a movement towards accomplishment, self-structuring and self-realization - the Gospel revelation is good news because it meets our most basic aspirations, to the point of revealing that life is stronger than death - and at the same time following Christ is a movement of self-transcendence, of transformation, of moving

38 S. de Fiores et T. Goffi, Dictionnaire de la vie spirituelle, Paris, Cerf 1987, p. 199.

39 J.-L. Souletie, La crise, une chance pour la foi, Paris, Éditions de l'Atelier 2002, p. 54. 
out of oneself - a dramatic transformation of our way of thinking and acting: loving our enemies, bearing the cross... At the heart of this tension, conversion is experienced in a mature way by successive developments, ${ }^{40}$ a conversion always searching for a greater stability and balance. The presence of converted catechumens, the stories of their journey, their sometimes difficult confrontation with the Gospel, their difficulty to endure in faith, reminds us of this.

Thus, the Christian faith can be seen as an ongoing process of conversion. This is something which the General Directory for Catechesis affirms: "Adhering to Jesus Christ, in fact, sets in motion a process of continuing conversion, which lasts for the whole of life." ( $\$ 56)$.

\section{Conversion, the catechumenal model and catechesis}

In the second half of the twentieth century, the process of Christian initiation, the catechumenate has been rethought because we have understood the importance of this process to promote a "strong" conversion of catechumens. ${ }^{41}$ With the belief that the perseverance of the neophytes depends on a process of conversion that can be part of a true initiation process, in a French document on the catechumenate in the sixties we read: "We always tend to go too fast, while for grace to do its work in the person's consciousness it takes time." ${ }^{42}$ The need for conversion, and a conversion process understood as revitalising the entire Christian life, is at the heart of these concerns, as we have already noted. If conversion is relative in an entire way to the Christian faith, then it also represents what Christian life itself is, since one never finishes becoming a Christian, thus converting. For Yves Congar, the whole Christian life is conversion, "every believer must seek to become, day after day, what s/he is, and achieve spiritual depth [...]. The Christian [...] is rigorously called to become truly Christian; in other words this is an obligation linked to conversion..." ${ }^{33}$

${ }^{40}$ On this, my remarks owe a lot to the reflection by the theologian Paul-André Giguère. Cfr P.-A. Giguere, Catéchèse et maturité de la foi, Montréal/Bruxelles, Novalis/Lumen Vitae, 2002, p. 83-94.

${ }^{41}$ In both countries with a Chrsitian "tradition" and mission countries.

${ }^{42}$ P. Audollent, Lentourage des convertis, Document du service national du catéchuménat, 1964.

${ }^{43}$ Y. Congar, La conversion..., p. 505-506. 
We can therefore consider baptism and Christian initiation as the symbols of this "permanent conversion". Conversion goes through a transformation for which baptism signifies the beginning, the death and the resurrection of Jesus, and the effect is the new birth. Pierre-André Liege also speaks of the conversion of catechumens as a "fundamental conversion, a conversion to a pure state." ${ }^{44} \mathrm{He}$ speaks of it as a "mature conversion." But for a return to God, we a need a "second conversion," and for the ordinary believer a "continuous conversion, a perpetual transition from a life in which God is insufficiently known to a converted life where God is profoundly known." ${ }^{45}$

It is interesting to note that in the catechumenate, catechumenal catechesis is considered as having its own proper style because it accompanies the conversion being experienced by the catechumens. If catechetical reflection for several years now has taken the inspiration of the model of the catechumenate seriously, has the notion of conversion been sufficiently questioned? In particular the necessity for an appropriate catechesis to accompany both the conversion taking place now and the "ongoing" conversion. Does this not become urgent in our contemporary secularised context and in our anthropological crisis? While Christianity for our contemporary society has become a choice among many other possibilities. While current conversions show that the Gospel can be received as a vitalising force in life. All this in a non-religious society about which the theologian Denis Villepelet says that "it is a chance for a new Christianity considered as a transformational and humanising strength." ${ }^{\prime 6}$

If the Christian initiation process is seen as a model, it is because it is a process implemented to support the work of grace in the entire catechumen. The concepts of faith and conversion are also inseparable in the Rite of Christian Initiation of Adults (RCIA). This ritual evokes two moments of transition: the "initial conversion" required for entry into the catechumenate and the "conversion" required for the decisive call. The "pastoral comments" often evoke the notion of conversion. There also peak of a "gradual change of mentality

${ }^{44}$ P.-A. Liégé, Reviens au Seigneur ton Dieu. La conversion chrétienne, Paris, Centre Saint-Yves 1959, p. 37.

45 P.-A. Liégé, Reviens au Seigneur ton Dieu. La conversion chrétienne, p. 38. Thus, if the baptized adults go from "conversion to baptism," baptized children go from "baptism to conversion."

46 D. Villepelet, Essai de problématisation de la nouvelle évangélisation, "Lumen Vitae" (2012-2), p. 150. 
and customs", of "ruptures", of "separation", of the "passage from death to life as a conversion passage." ${ }^{47}$... Well conversion then appears as something which matures by time. In Christian initiation, man responds to the gift of God through his conversion and faith, through all that s/he is, through corporeity, with the body. Hence the importance of the liturgy. ${ }^{48}$ In the RICA both the progressive transformation of the person and the key moments of this transformation that the liturgy activates are valued. In accordance with Christian initiation, you do not become a Christian only by catechesis or by conversations with those accompanying the person, but through accompaniment, catechesis and liturgical moments that prove to be decisive.

At the heart of the catechumenal model, the liturgy participates fully in supporting the conversion. Is not the liturgy a symbolic action which aims to establish or restore communication with God? According to Louis-Marie Chauvet, it is itself "the paradigm of communication between God and human beings", ${ }^{49}$ hence its role in the conversion process. Even Paul de Clerck writes that "The liturgy is the privileged place of encounter of Christians with God and Jesus Christ whom he sent." ${ }^{50}$ In the liturgy, we meet, we feel, we experience the presence of Christ: "A heartfelt gesture is worth all the discourse. The gesture is both body and words." 51

${ }^{47}$ During this itinerary, liturgical rites and the accompanying steps are essential. Articulated to be a support, they contribute to the conversion of the catechumens, as shown by the change in the name of each of the accompanying times: "Candidates", "catechumens" at the first step, "to be baptised", "to be illuminated", and "the elect" at the final call, "neophytes" after the reception of the three sacraments of Christian initiation.

48 The rite of the "scrutinies" are a good example. Repeated three times, they punctuate the baptismal journey of conversion. Through these rites God comes to visit and revitalise the interior freedom of catechumens. In this way the spiritual warfare in which they are involved and the break they have to make in life, are enlightened. Thus, approaching their baptism they can measure the distance between the call of Christ and what hinders them in their lives. The catechumens live intensely this repeated celebration of the scrutinies because it helps them to turn to the Lord for mercy. The rite of the scrutinies thus accompanies and supports the conversion process and allows this to be stamped in the depths of their hearts. At the same time, a certain ideal vision of the faith that they may have in the catechumenal journey gives way to the realism of an ongoing conversion.

49 L.-M. Chauvet, Le corps, chemin de Dieu. Les sacrements, “Theologia” Series, Paris, Bayard 2010, p. 63.

50 P. de Clerck, Pour la gloire de Dieu et le salut du monde, "La Maison-Dieu" 221 (2000-1).

${ }^{51}$ D. Villepelet, L'avenir de la catéchèse, Paris/Bruxelles, Ed. de l'Atelier/Lumen Vitae, 2003, p. 46. 
The catechumenal model thus implements a liturgy which is the source for conversion and faith. ${ }^{52}$ This new consideration of the liturgy demands a change in our usual way of thinking, which consists of spontaneously focusing on reflection and on the catechetical word, or on the moral dimension to promote a decision on the faith. The Second Vatican Council (Sacrosanctum Concilium, $\$ 7$ ) presents the liturgy as the space and the time where Christ's call and the response of the disciple is re-echoed in the light of Jesus' relationship with listeners in the Gospels, something which is typical of a situation of conversion. So entering into the liturgy means activating a major break (a conversion?), which helps to move from a situation of "words" (even in the form of exchange and conversation) to a position of listening to the Word and to a possible response to it. ${ }^{53}$ We can discuss spirituality and the Christian experience but through the liturgy we will be welcoming the call of the Gospels, "an addressed Word of God" 54 which calls for a response. It is undoubtedly in this sense that we must understand the current concept of "catechesis of initiation" 55 - a catechesis that the General Directory for Catechesis evokes as that which "accompanies the process of conversion" (\$ 89) - and of a "pedagogy of initiation." ${ }^{\prime \prime 6}$ The aim is for catechesis to find this basic foundation: to allow everyone to experience the closeness of Christ and to feel that his call touches everyone personally and allows everyone to realign oneself to it. Pope Francis puts us on track when he devotes several paragraphs of Evangelii Gaudium to what he calls a "kerygmatic and mystagogical catechesis.” (\$163-168).

52 "the liturgy is the summit toward which the activity of the Church is directed; at the same time it is the font from which all her power flows," Sacrosanctum Concilium, 10. Also, "To accomplish so great a work [the paschal mystery], Christ is always present in His Church, especially in her liturgical celebrations." (\$7).

${ }^{53}$ Cfr H.-J. Gagey, La liturgie, milieu de l’annonce de l'Évangile, in: F. Moog et J. Molinario, La catéchèse et le contenu de la foi, "Théologie à l'Université" Series, Paris, Desclée De Brouwer, 2011, p. 95-97.

${ }^{54}$ Cfr J.-L. Souletie et H.-J. Gagey (dir.), La Bible, Parole adressée, "Lectio Divina” Series $\mathrm{n}^{\circ} 183$, Paris, Cerf, 2001.

${ }^{55}$ Cfr H. Derroitte (dir.), Catéchèse et initiation, "Pédagogie catéchétique 18" Series, Bruxelles, Lumen Vitae, 2005.

${ }^{56}$ Cfr Conférence des évêques de France, Texte national pour lorientation de la catéchèse en France et principes d'organisation, Paris, Bayard éditions /Fleurus-Mame/Cerf, 2006. 


\section{Stories of Conversion}

I have already mentioned the importance of the narrative identity as a constitutive aspect of conversion. Finally, in preparation for our work, I shall quickly mention conversion stories. For many, conversion to Christianity is expressed through a story. ${ }^{57}$ The typical example is that of St Augustine. Marie-Anne Vannier even says that with Augustine, "subjectivity enters into the history of thought." ${ }^{8}$ Danièle Hervieu-Léger states that even today, "it is certainly conversion narratives that offer the richest material to identify the variety of compositions that the converted implement progressively, starting from a provoking experience." ${ }^{.59}$ These are analyses that are made departing from the subjectivity of the converted, evoking stories of profound changes, touching their identity, their relationship to the world, that which gives direction, coherence and meaning to their existence.

With conversion narratives we are dealing with what Étienne Grieu calls "confessing stories." ${ }^{60}$ These stories have the theme of becoming a Catholic Christian. They speak of the access of these witnesses to a singular word, beyond what was determined in advance. It is a way for them to revisit and describe their past and assert the new orientation in life. Grieu claims that: "Narrating one's story is transcending it." ${ }^{\text {"1 }}$ At the same time, the story captures the interiority of the subject in a new way. But we must not forget that the story remains unfinished. We do not have the end of the plot. We have, in addition, to deal with a surplus of meanings which go beyond our own understanding, even a "theological" one.

In the story, the person reveals both what has happened and the significance given to these events. We are more interested in understanding this explanation rather than the description of events. Understanding what has influenced the

${ }^{57}$ C. Decobért, Conversion, tradition, institution, Archives de sciences sociales des religions, 116, octobre- décembre 2001, put online on $2^{\text {nd }}$ November 2002, consulted on $12^{\text {th }}$ March 2015. http://assr.revues.org/541 (8.06.2016), p. 5.

58 A.-M. Vannier, La conversion, constitutive du sujet Augustin, in: B. Bakhouche, I. Fabre, V. Fortier, Dynamiques de conversion..., p. 73.

59 D. Hervieu-Léger, L'impératif de la conversion..., p. 15.

${ }^{60}$ E. Grieu, Nés de Dieu. Itinéraires de chrétiens engagés. Essai de lecture théologique, "Cogitatio fidei" Series, Paris, Cerf, p. 76.

${ }^{61}$ E. Grieu, Nés de Dieu. Itinéraires de chrétiens engagés, p. 79. 
person, how the identity as a believer was formed, what were the different forms of the experience of conversion - identity, psychological and social dynamics, but most of all as a believer: by a witness through an awareness which triggers a search, through an event, through a reflection that brought about a change of life ... which, from an initial situation was favourable or unfavourable... all this helps us to calibrate our catechetical work, with an element which is beyond our control. For if the converted shares the story in an "objective" way, how can we understand God's "silent" call?

\section{Conclusion}

For Odile Arnold, conversion remains a "secret of God." She adds that it is important to continue having conversions, no one can provoke the response of the human being to God, even if this may be a temptation of the catechist. For the philosopher Catherine Chalier it is also the "secret" of converts: "If many converts remain discreet in this respect, it is not to protect some shameful secret, but rather to let them cultivate and grow in themselves the radiance of a truth they perceive with gratitude and amazement, which orients their lives but escapes any form of appropriation." ${ }^{20}$ The diversity of conversion experiences, as we noted in the introduction asks us to abandon the myth that there is only one way to live Christianity.

In this regard, Étienne Grieu studying a "Christianity of conversion"63 offers the "rethinking of a 'great Church,", 64 'to "allow as many people to somehow enjoy the Gospel and the hope that it brings". ${ }^{65}$

I will conclude my input with this reflection of this theologian who, in my opinion is in line with the theme we are studying: In recent decades, the Catholic Church stressed on the importance of the liturgy and the sacraments - in

${ }^{62}$ C. Chalier, Le désir de conversion, Paris, Seuil, 2011, p. 29.

${ }^{63}$ The expression "Christianity of conversion" appears in the book: S. Fath (dir.), Le protestantisme évangélique, un christianisme de conversion. Entre ruptures et filiations, "Sciences Religieuses de l'EPHE” Series, Turnhout, Brépols, 2004. Cfr also E. Grieu, L'Église catholique et le christianisme de conversion, Documents-Épiscopat, 8/2010.

${ }^{64}$ E. Grieu, Réinventer la 'grande Église', Études 11/2008 (Tome 409), p. 495-505, www. cairn.info/revue-etudes-2008-11-page-495.htm (8.06.2016).

${ }^{65}$ E. Grieu, Réinventer la 'grande Église', \$23. 
resonance with meditation of the Biblical texts. We have not finished discovering these texts and they still amaze us with their ability to strengthen, encourage, and revive people as communities. Many initiatives can result from this momentum. In addition to this first element, I will remark on a second element which is often less emphasized. I believe that a renewed dynamism of the great Church also means rediscovering its spiritual traditions. These ways of being Christian, marked initially by extremely strong personal experiences, have found a way to be communicated to more persons with the scope of helping them to walk with Christ. These schools of spirituality contain real proposals of conversion and evangelization in the heart of human experience, opening the possibility for Christians to allow the Lord to invite them to places which up to now have been forbidden. Through such spiritual work, many people can find their specific way to respond to God, and they do this throughout all their lives. Their faith, rather than expressing respect for norms, speaks of a God who walks with them. ${ }^{66}$

Translated by Carl-Mario Sultana, University of Malta

${ }^{66}$ E. Grieu, Réinventer la 'grande Église', $\$ 25$. 